\title{
STRATEGI PENINGKATAN MUTU TEMBAKAU BESUKI NA-OOGST DI PTPN X KEBUN KERTOSARI JEMBER
}

\author{
Auliana Khoirun Nisa*1, Rudi Wibowo*) dan M. Rondhi*) \\ *) Program Studi Agribisnis, Fakultas Pertanian, Universitas Jember \\ Jl. Kalimantan No. 37, Jember, Jawa Timur 68121
}

\begin{abstract}
PTPN X Kebun Kertosari is a tobacco agribusiness company. In the period of 2010-2014, the quality of tobacco declined annually, and the plantation was unable to achieve its quality target. The objectives of this research are: (1) to identify the causes of failure of the company in achieving its target of Besuki Na-Oogst tobacco, and (2) to identify strategies in improving the working performance of PTPN X Kebun Kertosari. The primary data were collected from observations and focused group discussions while the secondary data were obtained from the company archives of data on production and quality of tobacco. The research method was an analytical descriptive using the data analysis methods of fishbone diagram, Pareto diagram and Analytical Hierarchy Process (AHP). The results showed that factors affecting the quality of the Besuki Na-Oogst tobacco of PTPN X Kebun Kertosari include the human resources, methods, materials, machines and environment. The main cause of degradation of tobacco quality (80\%) is labor negligence, and lack of labor skills contributes as much as $26.7 \%$. The alternative strategy prioritized to improve the quality of the performances of the company human resources. The result of the research recommends the company to provide assistance and monitoring to its employees so that negligence and errors in production can be minimized, and the company should focus and pay attention to its human resource quality, thus increasing the performance quality of Besuki Na-Oogst tobacco of PTPN X Kebun Kertosari.
\end{abstract}

Keywords: tobacco besuki Na-Oogst, quality performance, fishbone diagram, pareto diagram, analyticaal hierarchy process

\begin{abstract}
ABSTRAK
PTPN X Kebun Kertosari adalah perusahaan agribisnis komoditas tembakau. Pada tahun 2010-2014 mutu tembakau semakin menurun setiap tahunnya dan tidak mampu mencapai target mutu. Penelitian bertujuan (1) mengetahui penyebab mutu tembakau Besuki Na-Oogst di PTPN $X$ Kebun Kertosari tidak mampu mencapai target dan (2) mengetahui strategi peningkatan kinerja mutu PTPN X Kebun Kertosari. Metode penelitian dilakukan secara deskriptif analitik dengan metode analisis data diagram tulang ikan, diagram pareto dan Analitycal Hierarchy Process (AHP). Hasil penelitian menunjukkan faktor yang memengaruhi mutu tembakau Besuki Na-Oogst di PTPN X Kebun Kertosari mengalami penurunan sehingga tidak mampu mencapai target disebabkan oleh SDM, metode, bahan baku, mesin dan lingkungan. Hasil analisis Pareto menunjukkan penyebab utama $80 \%$ penurunan mutu, yaitu kelalaian dan kurangnya keterampilan tenaga kerja (SDM) yang menyumbang 26,7\%. Strategi alternatif yang diprioritaskan untuk peningkatan kinerja mutu, yaitu peningkatan kualitas SDM. Hasil penelitian merekomendasikan perusahaan agar melakukan pendampingan dan monitoring terhadap tenaga kerja agar dapat mengurangi kelalaian dan kesalahan proses produksi serta lebih fokus dan memperhatikan kualitas SDM untuk meningkatkan kinerja mutu tembakau Besuki Na-Oogst di PTPN X Kebun Kertosari.
\end{abstract}

Kata kunci: tembakau besuki Na-Oogst, kinerja mutu, diagram tulang ikan, diagram pareto, analisis proses hirarki

\footnotetext{
${ }^{1}$ Alamat Korespondensi:

Email: inatipub@gmail.com
} 


\section{PENDAHULUAN}

Tembakau adalah tanaman perkebunan yang merupakan komoditas unggulan Kabupaten Jember. Wilayah sentra penanaman tembakau di Kabupaten Jember, yaitu Jember utara-timur terutama di Kecamatan Arjasa, Sumberjambe, Ledokombo, Kalisat, Pakusari dan Sukowono. Putri et al. (2015) menyatakan tembakau tanaman yang membutuhkan perawatan intensif, sejak masa persiapan, pengolahan tanah, penanaman, pemupukan, penyulaman, pengairan, penyiangan, penyemprotan, pemetikan dan pasca panen.

PTPN X Kebun Kertosari adalah perusahaan yang bergerak dibidang tanaman perkebunan komoditas tembakau. PTPN X Kebun Kertosari memproduksi dan mengekspor tembakau cerutu yang terdiri dari Tembakau Na-Oogst dan Tembakau Bawah Naungan (TBN). Proses produksi dimulai dari kegiatan on farm sampai off farm. Pengusahaan Tembakau Besuki NaOogst di PTPN X terdiri dari tiga tahapan kegiatan, yaitu tahap budi daya, pengeringan dan pengolahan.

Hasil produksi tanaman tembakau di PTPN X Kebun Kertosari 100\% diekspor. Harga tembakau ditentukan oleh kualitas tembakau. Kualitas tembakau Besuki $\mathrm{Na}$ Oogst dibedakan menjadi tiga, yaitu dekblad, omblad dan filler. Tembakau kualitas dekblad digunakan sebagai pembalut luar cerutu sehingga menuntut kualitas tembakau yang tinggi, tembakau jenis ini memiliki nilai ekonomis lebih tinggi dari omblad dan filler. Tembakau kualitas omblad digunakan sebagai pembungkus dilapisan kedua dan harus memiliki rasa yang khas. Tembakau filler digunakan sebagai pengisi cerutu, harus memiliki rasa yang dominan karena sangat menentukan taste yang khas. Proses produksi perusahaan tidak hanya memperhatikan kuantitas, tetapi juga mempertimbangkan kualitas atau mutu tembakau.

Permasalahan pada perusahaan ini, yaitu perusahaan mampu mencapai mutu dekblad pada tahun 2010 dan 2011, pada tahun 2012 tidak melakukan produksi, pada tahun 2013 dan 2014 perusahaan tidak mampu mencapai mutu dekblad dengan target yang telah ditetapkan dan semakin mengalami penurunan produksi dari $0,3 \%$ tahun 2013 menjadi 0\% tahun 2014. Mutu omblad mampu mencapai dan melebihi target mulai dari tahun 2010-2014. Pada mutu filler, perusahaan tidak mampu mencapai target yang telah ditentukan oleh perusahaan, mutu filler mengalami penurunan secara terus menerus mulai dari tahun 2010 sampai 2014. Mutu yang semakin menurun dan tidak mampu mencapai target yang telah ditetapkan menyebabkan pihak perusahaan mengalami kerugian. Adanya penurunan mutu tersebut merupakan salah satu indikator kinerja perusahaan semakin menurun.

Beberapa penelitian yang berkaitan dengan manajemen mutu antara lain Tisnowati et al. (2008), Soetjitro (2010) dan penelitian Rusdianto et al. (2011), penelitian oleh Ramadhani et al. (2014), kemudian penelitian Darmasetiawan dan istiko (2012), penelitian selanjutnya dilakukan oleh Mayangsari et al. (2014) dan Diatin et al. (2006) serta penelitian Utami et al. (2014) hasil penelitian tersebut menyatakan bahwa faktor utama yang berpengaruh dan menjadi penyebab permasalahan kinerja mutu adalah faktor Sumber Daya Manusia (SDM), metode, bahan baku dan permesinan. Pada penelitian-penelitian tersebut menyatakan bahwa penyebab penurunan mutu dapat dianalisis dengan diagram Pareto dan diagram tulang ikan.

Tujuan penelitian ini mengetahui penyebab penurunan mutu tembakau Besuki Na-Oogst dan mengetahui strategi peningkatan kinerja mutu perusahaan dengan menganalisis kondisi dan gambaran pada proses pengolahan tembakau, serta menganalisis faktor penyebab terjadinya penurunan mutu tembakau Besuki Na-Oogst PTPN X Kebun Kertosari.

Ruang lingkup penelitian mencakup strategi peningkatan mutu tembakau Besuki $\mathrm{Na-Oogst}$ berbasis perbaikan kinerja mutu dan identifikasi penyebab permasalahan yang berpengaruh terhadap penurunan mutu tembakau. Penelitian ini difokuskan untuk merumuskan strategi dan upaya meningkatkan kinerja mutu PTPN X Kebun Kertosari.

\section{METODE PENELITIAN}

Lokasi penelitian dilakukan secara sengaja pada PTPN X Kebun Kertosari berdasarkan pertimbangan Kecamatan Pakusari, Kalisat, Sukowono dan Ledokombo merupakan kecamatan yang berada pada lima besar produksi tembakau tertinggi di Kabupaten Jember, penelitian dilakukan pada tahun 2016.

Analisis dilakukan dengan metode deskriptif analitis. Metode deskriptif untuk menggambarkan fenomena 
faktual dan akurat mengenai fakta, sifat serta hubungan antar fenomena yang diselidiki, yaitu penyebab kualitas produksi tembakau Besuki Na-Oogst PTPN $\mathrm{X}$ Kebun Kertosari tidak mampu mencapai target. Metode analitis digunakan untuk menganalisis strategi peningkatan kinerja PTPN X Kebun Kertosari.

Metode pengumpulan data primer dilakukan dengan observasi, Focus Group Discussion (FGD) dan wawancara. Data sekunder diperoleh dari Badan Pusat Statistik, dokumen kantor PTPN X Kebun Kertosari. Metode penentuan responden dilakukan secara sengaja, yaitu manajer pengolahan, asisten manajer, juru teknik fermentasi, sortasi tahap I/II, sortasi tahap III/IV, sortasi filler, sortasi dekblad/omblad, juru teknik nazien/nametten dan juru teknik pengebalan.

Analisis yang digunakan menguji faktor penyebab kualitas tembakau Besuki Na-Oogst PTPN X Kebun Kertosari tidak mampu mencapai target dianalisis secara deskriptif dengan diagram tulang ikan. Ishikawa (1989) diagram tulang ikan untuk mengilustrasikan dengan jelas bermacam-macam penyebab yang memengaruhi mutu produk melalui pemilihan dan pengembangan penyebab penurunan mutu. Nasution (2005) menyatakan langkah analisis diagram tulang ikan, yaitu 1) mendapatkan masalah yang terjadi; 2) menemukan penyebab menggunakan teknik brainstorming; 3) menggambar diagram, masalah ditempatkan (membentuk kepala ikan). Penyebab kategori utama ditempatkan pada cabang utama (membentuk tulang ikan); 4) menetapkan faktor penyebab utama, dengan menempatkan pada cabang utama; 5) menemukan akar penyebab, kemudian tuliskan pada cabang sesuai kategori utama; 6) menginterpretasikan diagram sebabsebab; 7) menerapkan hasil analisis dengan diagram tulang ikan.

Setelah dianalisis dengan diagram tulang ikan, faktor yang menyebabkan mutu tembakau Besuki Na-Oogst di PTPN X Kebun Kertosari menurun dianalisis secara kuantitatif dengan diagram pareto. Rusdianto et al. (2011) menyatakan diagram pareto adalah alat untuk membandingkan berbagai kategori kejadian yang disusun menurut ukurannya, dari yang paling besar disebelah kiri ke yang paling kecil di sebelah kanan. Chandra (2013) langkah analisis diagram pareto, yaitu menentukan masalah yang diteliti, membuat daftar frekuensi dari masalah, membuat daftar masalah berurutan berdasarkan frekuensi kejadian, serta menghitung frekuensi kumulatif, persentase total kejadian dan persentase dari total kejadian secara kumulatif, menggambar garis vertikal (Frekuensi) dan horizontal (penyebab penurunan mutu), membuat histogram diagram pareto, menggambar kurva kumulatif, memutuskan tindakan perbaikan atas penyebab utama masalah yang terjadi.

Analytic Hierarchy Process (AHP) adalah suatu model yang luwes yang memberikan kesempatan bagi perorangan atau kelompok membangun gagasan dan mendefinisikan persoalan dengan membuat asumsi mereka dan memperoleh pemecahan sesuai dengan dirinya. Beberapa penelitian AHP, yaitu Djarwadi (2012) menyatakan bahwa AHP adalah kerangka pengambilan keputusan yang kompleks, Hastuti (2010) menyatakan AHP merupakan model hierarki yang terdiri dari tujuan, kriteria dan beberapa subkriteria serta alternatif untuk masing-masing permasalahan atau keputusan. dan penelitian Widyastutik dan Kristina (2013) menyatakan bahwa AHP menunjukkan rekomendasi strategi peningkatan mutu benda.

Hipotesis pada penelitian ini, yaitu mutu tembakau Besuki Na-Oogst di PTPN X Kebun Kertosari yang tidak mampu mencapai target disebabkan oleh beberapa hal, yaitu SDM, metode, bahan baku (berupa tembakau opstapel, mesin dan lingkungan). Penyebab utama terjadinya penurunan mutu tembakau Besuki Na-Oogst di PTPN X Kebun Kertosari, yaitu kelalaian dan keterbatasan keterampilan SDM. Strategi utama atau yang diprioritaskan untuk meningkatan kinerja mutu tembakau Besuki Na-Oogst PTPN X Kebun Kertosari, yaitu kualitas SDM. Strategi pendukungnya, yaitu sistem proses terintegrasi, sarana proses produksi, perlakuan (treatment) untuk menghadapi perubahan lingkungan, kemudian research and development. Faktor yang memengaruhi mutu tembakau Besuki $\mathrm{Na}$-Oogst di PTPN X Kebun Kertosari tidak mampu mencapai targetnya disebabkan oleh SDM, strategi peningkatan mutu.

Penelitian ini diawali dari fenomena terjadinya penurunan mutu tembakau Besuki Na-Oogst di PTPN $\mathrm{X}$ Kebun Kertosari dan sebagian besar produk yang dihasilkan bermutu rendah. Berdasarkan fenomena tersebut peneliti ingin mengetahui faktor penyebab penurunan mutu tembakau Besuki Na-Oogst dianalisis dengan diagram tulang ikan dan diagram Pareto. Selain itu untuk mengetahui strategi dan upaya untuk meningkatkan kinerja mutu perusahaan dengan menganalisis melalui AHP. Hasil penelitian ini 
diharapkan mampu merumuskan strategi dan upaya untuk meningkatkan kinerja mutu tembakau Besuki Na-Oogst di PTPN X Kebun Kertosari. Kerangka penelitian ini dapat dilihat pada Gambar 1.

\section{HASIL}

\section{Mutu Tembakau Besuki Na-Oogst di PTPN X Kebun Kertosari}

Mutu tembakau Besuki Na-Oogst di PTPN X Kebun Kertosari dibedakan menjadi dekblad, omblad, dan filler. Dekblad adalah pembalut luar cerutu, sehingga menuntut kualitas yang sangat bagus dan memiliki nilai ekonomis tinggi. Omblad adalah pembungkus dalam cerutu, memiliki nilai ekonomis lebih rendah dari dekblad. Filler adalah isian cerutu, terendah dan nilai ekonomisnya rendah. Pengusahaan tembakau Besuki Na-Oogst di PTPN X Kebun Kertosari terbagi menjadi tiga tahapan, yaitu budiaya, pengeringan (curing) dan pengolahan. Setiap tahapan memiliki titik kritis. Titik kritis pada tahap budi daya, yaitu penentuan bibit, pengolahan tanah, pemeliharaan dan pemanenan. Titik kritis tahap curing, yaitu proses sortasi, sujen, pengasapan, dan romposan. Titik kritis tahap pengolahan, yaitu turun truk, saring rompos, fermentasi, bir-biran, sortasi, nazien, nametten dan pengebalan.

Pelitian ini membahas mengenai pengolahan mutu tembakau Besuki Na-Oogst di PTPN X Kebun Kertosari. Beberapa tahun terakhir mutu tembakau tidak mampu mencapai target yang ditentukan, sehingga perlu adanya upaya atau strategi untuk meningkatkan kinerja perusahaan untuk mencapai target yang ditentukan.

\section{Diagram Tulang Ikan pada Mutu Tembakau Besuki Na-Oogst PTPN X Kebun Kertosari}

Faktor penyebab mutu tembakau Besuki Na-Oogst mengalami penurunan dan tidak mampu mencapai target dianalisis dengan diagram tulang ikan. Hasil analisis menunjukkan faktor yang berpengaruh terdapat 5 elemen, yaitu SDM, metode, bahan baku, mesin dan lingkungan. Setiap elemen terdapat beberapa akar penyebab yang berpengaruh terhadap mutu tembakau Besuki Na-Oogst. Berikut merupakan kerangka analisis diagram sebab akibat mutu tembakau Besuki Na-Oogst PTPN X Kebun Kertosari.

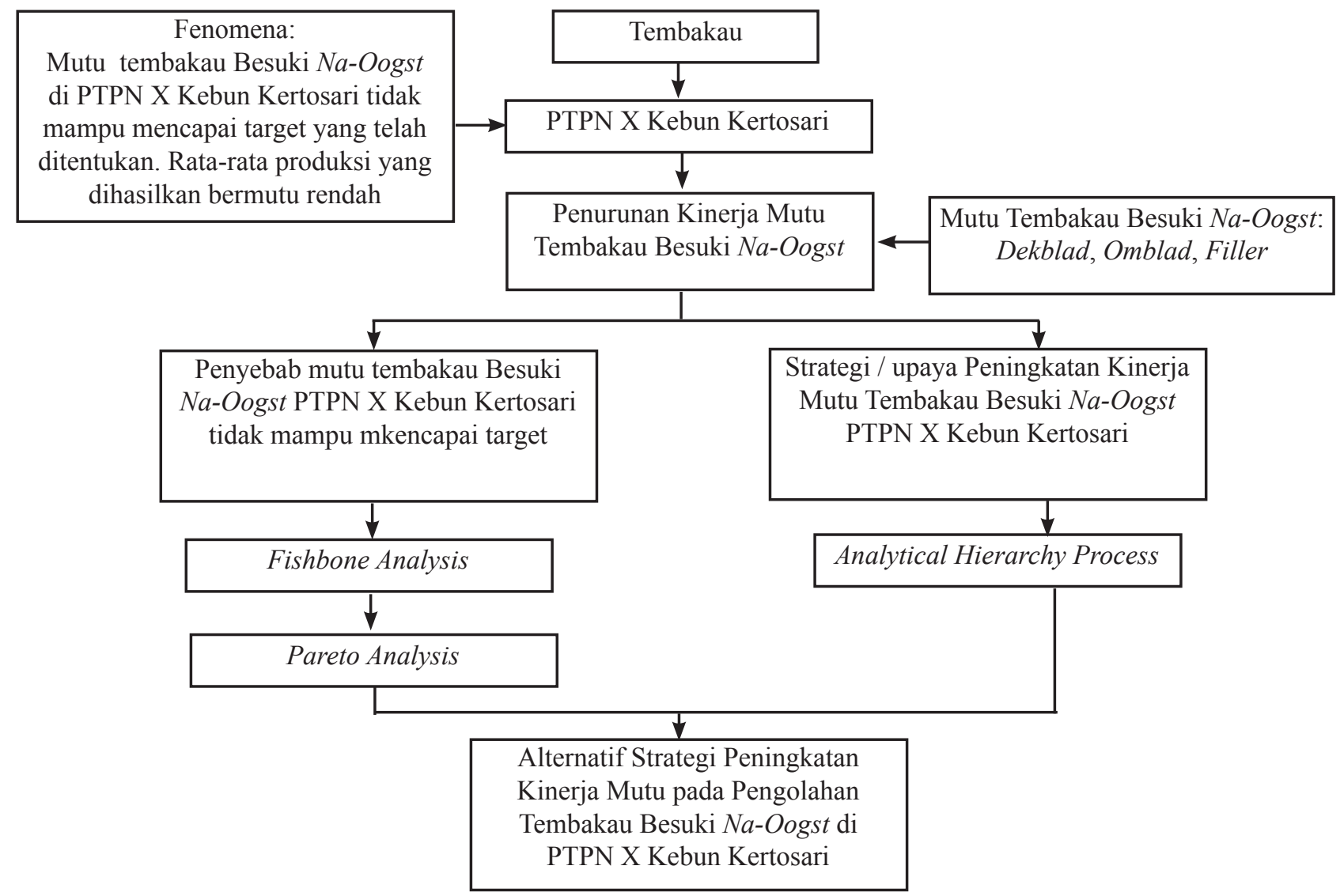

Gambar 1. Kerangka pemikiran penelitian 
Pada Gambar 2 diperoleh informasi bahwa elemen yang memengaruhi penurunan mutu tembakau Besuki Na-Oogst PTPN X Kebun Kertosari terbagi menjadi lima elemen, yaitu SDM, bahan baku, metode, mesin, dan lingkungan. Setiap elemem permasalahan memiliki akar penyebab masing-masing. Berikut penjeasan mengenai akar permasalahan yang menyebabkan penurunan mutu tembakau Besuki $\mathrm{Na-Oogst}$ di PTPN X Kebun Kertosari.

\section{Sumber Daya Manusia (SDM)}

Sumber Daya Manusia (SDM) merupakan pelaku utama pada proses produksi yang memiliki peranan penting dalam keseluruhan kegiatan, SDM memiliki beberapa akar penyebab yang memengaruhi mutu tembakau Besuki Na-Oogst di PTPN X Kebun Kertosari, yaitu sebagai berikut:

\section{Kelalaian tenaga kerja atau petugas}

Kelalaian tenaga kerja atau petugas dapat terjadi pada seluruh tahapan proses produksi, mulai dari budi daya, pengeringan dan pengolahan. Seperti penanganan pada tembakau yang kekurangan air, yaitu tembakau yang berwarna kuning apabila petugas lalai menangani atau terlambat memberikan perlakuan maka tembakau tersebut tidak akan bisa digunakan atau tidak dapat diselamatkan, sehingga mutu tembakau ini tidak dapat dijual dipasar. Kelalaian petugas dapat menurunkan mutu tembakau baik menjadi tembakau cacat.

\section{Keterbatasan pengalaman tenaga kerja}

Pengalaman petugas diperlukan pada keseluruhan proses budi daya, pengeringan dan pengolahan, seperti pada tahap fermentasi dibutuhkan sekitar tiga orang, yaitu penumpuk tembakau, pengangkut dan petugas bersih-bersih/sapu, petugas penumpuk dan pengangkut harus memiliki pengalaman sesuai bidangnya, karena jika proses ini dilakukan petugas yang tidak berpengalaman, tumpukan tembakau akan miring dan roboh. Biasanya pengangkut dapat belajar menumpuk tembakau (stapelan) dari penumpuk yang dilayani, proses pembelajaran ini yang menjadi pengetahuan para petugas untuk memahami cara fermentasi, jadi proses fermentasi hanya dapat dikerjakan oleh petugas berpengalaman. Sebagian besar tenaga kerja bekerja sekitar 20-25 tahun dan lainnya sekitar 10-20 tahun, juga terdapat tenaga kerja yang baru direkrut.

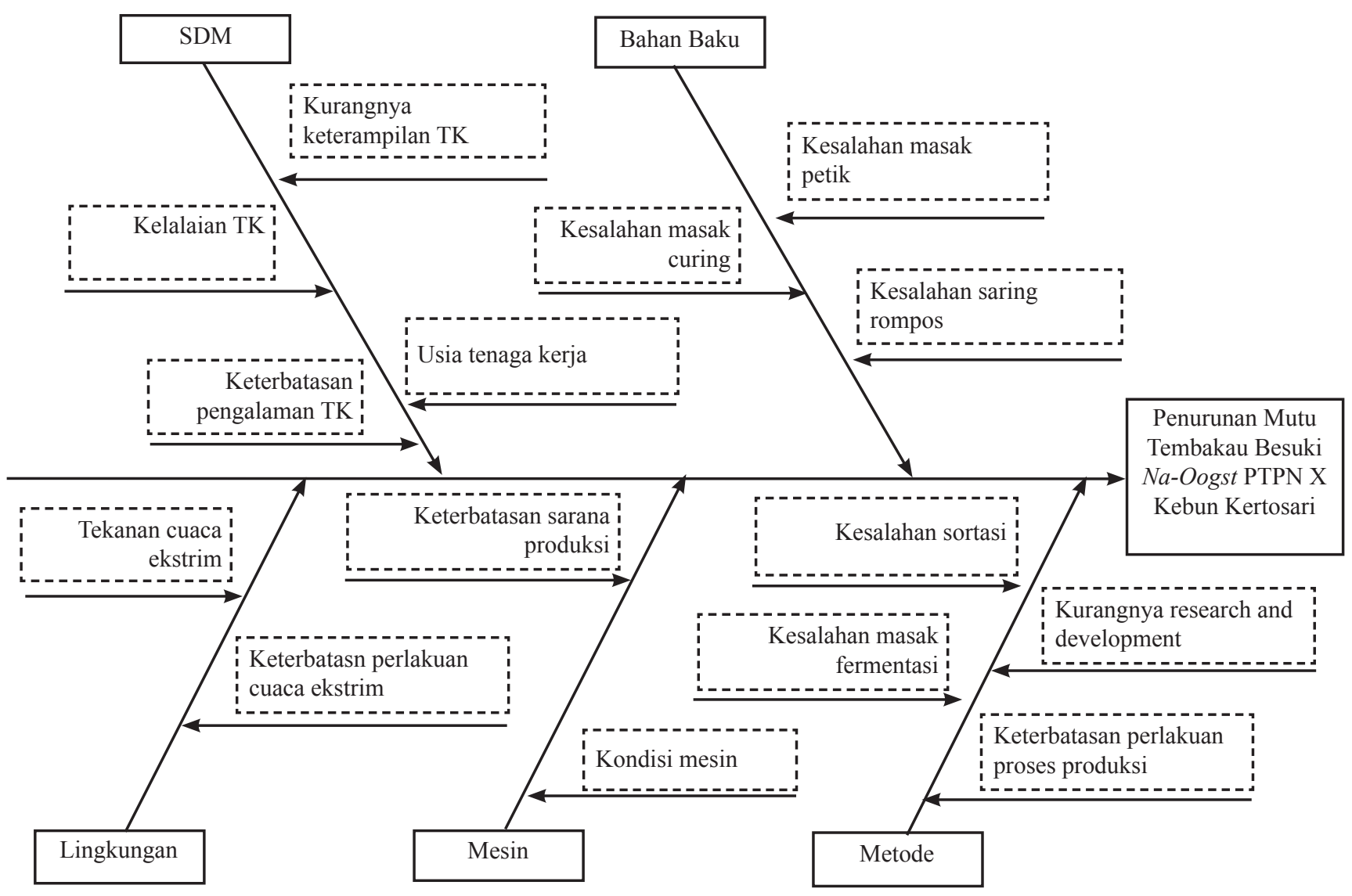

Gambar 2. Diagram tulang ikan mutu tembakau Besuki Na-Oogst PTPN X Kebun Kertosari 
Kurangnya keterampilan tenaga kerja

Keterampilan petugas sangat dibutuhkan pada seluruh tahapan kegiatan produksi, mulai dari budi daya, pengeringan dan pengolahan. Seperti pada proses saring rompos (romposan), fermentasi, bir-biran, sortasi, nazien, nametten dan pengebalan, semua proses ini memiliki titik kritis yang hanya dapat dilakukan oleh petugas yang terampil, apabila petugas tidak terampil maka akan menimbulkan kerusakan dan permasalahan. Seperti pada tahapan fermentasi membutuhkan petugas yang mampu mengkondisikan tekanan dan keadaan fermentasi, petugas harus mampu memahami kondisi tembakau dan memberikan perlakuan sesuai kondisi tembakau, petugas yang terampil akan menemukan berbagai cara dalam hal penanganan kondisi tembakau.

Usia tenaga kerja atau petugas

Usia petugas di PTPN X Kebun Kertosari berkisar antara 17-55 tahun. Tenaga kerja yang ada di gudang Sukowono $40 \%$ berusia diatas 46 tahun. Hal ini menunjukkan sebagian besar tenaga kerja memasuki usia tua, sehingga kondisi kesehatannya semakin menurun. Seperti pada proses turun truk dibutuhkan tenaga kerja usia muda 17-45 tahun karena memiliki tenaga yang kuat, sedangkan tenaga kerja yang sudah berusia 46-55 tahun jika dipaksakan melakukan kegiatan tersebut akan memengaruhi prouktivitas dan target yang ditentukan, karena sudah tidak bertenaga layaknya tenaga kerja muda.

\section{Bahan Baku}

Bahan baku yang digunakan pada pengolahan tembakau, yaitu tembakau opstapel atau tembakau hasil pengeringan di gudang bambu. Bahan baku yang baik akan menghasilkan tembakau baik, sedangkan tembakau yang kurang baik akan diberi perlakuanperlakuan selama pengolahan agar mampu mencapai kualitas. Bahan baku memiliki akar penyebab yang memengaruhi mutu tembakau Besuki Na-Oogst di PTPN X Kebun Kertosari:

Kesalahan masak petik

Salah satu syarat bahan baku yang baik, yaitu memenuhi syarat masak petik. Ciri-ciri tembakau yang telah masak petik, yaitu berumur \pm 45 hari, secara generatif sudah tumbuh bunga $60 \%$ dari seluruh tanaman, secara visual daun tembakau sedikit merunduk dan lulus uji klorofil pada daun. Tembakau yang salah petik akan berpengaruh terhadap proses dan tahapan selanjutnya, kondisi ini juga berpengaruh terhadap kualitas tembakau, seperti tembakau yang tidak memenuhi umur telah dipetik, setelah dilakukan pengolahan, hasil yang diperoleh akan cacat seperti aroma kurang khas, daya bakar rendah dan lain-lain.

\section{Kesalahan masak curing}

Masak curing adalah kegiatan pengasapan dimulai dari kegiatan sujen daun tembakau, setiap sujen terdiri dari 40 lembar daun yang kemudian diasap di gudang bambu selama 20-22 hari, ciri tembakau masak curing, yaitu daun tembakau berubah warna dari hijau menjadi coklat dan ganggang daun mengering dan terasa seperti kawat. Masalah pada daun tembakau seperti adanya kriteria kemasakan daun, sedangkan umur pengasapan belum mencapai standar, tembakau tersebut diberi perlakuan kusus seperti penggunaan anglo, perbaikan sirkulasi udara serta mengakhiri proses pengasapan. Bahan baku yang telah masak curing akan mudah diolah di gudang pengolahan, sedangkan tembakau yang tidak masak curing membutuhkan perlakuan khusus untuk menghasilkan tembakau yang baik.

\section{Kesalahan romposan}

Romposan adalah kegiatan sortasi dasar setelah dilakukan pengasapan, yaitu memisahkan tembakau yang busuk pada satu sujen agar tidak tercampur dengan tembakau yang baik pada saat diunting (diikat beberapa lembar krosok), kesalahan romposan dapat menularkan busuk dari daun yang busuk dan daun yang gagal pada saat pengasapan kepada daun yang sehat, sehingga perlu adanya ketelitian agar tidak terjadi kesalahan, hal ini tentu dapat memengaruhi keberhasilan pada tahapan selanjutnya.

\section{Metode}

Metode adalah elemen yang sangat berpengaruh terhadap mutu tembakau Besuki Na-Oogst di PTPN X Kebun Kertosari. Metode yang digunakan pada proses pengolahan sebagian besar masih metode sederhana dan masih tradisional. Metode produksi yang berperan penting dan memengaruhi mutu tembakau, yaitu sortasi, fermentasi dan perlakuan proses produksi. 


\section{Kesalahan sortasi}

Pada tahap pengolahan, sortasi dilakukan berkali-kali pada saat saring rompos, sortasi tahap 1, 2, 3 dan 4, nazien dan nametten. Saring rompos, yaitu memisahkan tembakau berdasarkan mutu dekblad, omblad, filler dan non produk. Sortasi tahap 1 memisahkan tembakau berdasarkan warna merah, kuning dan biru. Sortasi tahap 2 memisahkan tembakau berdasarkan tipis, sedang, tebal, open (tembakau kesat, warna tegas), dan close (tembakau elastis, minyak dan warna redup/kalem). Sortasi tahap 3 memisahkan tembakau berdasarkan warna kuning pucat, kuning, kuning semburat merah, merah, merah tua, merah bata, biru, biru tua dan biru. Sortasi tahap 4 unting halus tembakau. Nazien, yaitu pengelompokan tembakau berdasarkan ukur, mutu dan warna. Nametten, yaitu menyamakan warna, ukuran, mutu setiap untingan dalam satu ball kemasan. Kesalahan proses sortasi awal berpengaruh pada tahapan fermentasi, sortasi tahap 1,2,3 dan 4, nazien dan nametten terjadi kesalahan akan menyebabkan mutu tidak seragam, jika hal ini diketahui konsumen, maka perusahaan akan mendapat teguran dari konsumen.

\section{Kesalahan masak fermentasi}

Keberhasilan fermentasi ditandai oleh warna daun tembakau merata, aroma khas cerutu, elastis tinggi, daya bakar tinggi dan rasa yang tidak terlalu kuat. Sebelum fermentasi, tembakau dipisahkan sesuai mutu agar perlakuan setiap stapelan tembakau seragam. Fermentasi terdiri dari beberapa tahapan, yaitu stapel A, B, C dan D. Keterlambatan membongkar stapelan menyebabkan tembakau terlalu masak, terlalu cepat bongkar menyebabkan tembakau mentah sehingga perlu dilakukan fermentasi ulang. Tembakau lemas dan keras memiliki perlakuan yang berbeda, tembakau lemas direkondisi dengan anglo agar lebih keras dan layak stapel, tembakau keras direkondisi dengan daun keduyo agar lebih lemas dan layak stapel. Petugas harus peka dan terampil terhadap kondisi tembakau, karena ini adalah tahap terpenting untuk memperoleh tembakau berkualitas, kesalahan menyebabkan kegagalan produk dan dapat merugikan perusahaan.

\section{Kurangnya penelitian dan pengembangan}

Pada perusahaan ini telah dilakukan penelitian oleh berbagai pihak seperti mahasiswa dan peneliti yang lainnya, akan tetapi pengembangannya hanya sedikit, pengembangan ini dibatasi karena saat ini peralatan dan bahan yang digunakan dianggap mampu mencapai kualitas tembakau yang baik serta tidak menghabiskan banyak biaya. Sehingga untuk melakukan pengembangan harus melalui percobaan dan pertimbangan dari manajemen pusat.

\section{Keterbatasan perlakuan proses produksi}

Pada proses pengolahan terdapat beberapa perlakuaan yang diterapkan. Perlakuan pada saring rompos, yaitu ketika tembakau kotor dan tingkat kotornya tidak dapat ditoleransi maka petugas memberi perlakuan dengan menyikat daun tembakau agar dapat diproses ditahap selanjutnya. Perlakuan pada fermentasi, yaitu sering terjadi tembakau teralu keras dan terlalu lemas, sehingga tidak layak stapel, dilakukan perlakuan dengan cara mengangin-anginkan tembakau yang lemas kemudian ditumpuk dan diletakkan anglo agar tembakau lebih kaku dan layak stapel, tembakau yang terlalu keras dilakukan pelemasan dengan mencampurkan daun keduyo pada tumpukan tembakau sampai tembakau sedikit lemas dan dinyatakan layak stapel, perlakuan lain dilakukan sesuia dengan kebutuhan tembakau, hal ini dilakukan sesuai kepekaan petugas terhadap kondisi tembakau, apabila terlambat dan salah memberikan perlakuan akan merusak daun tembakau.

\section{Mesin}

Mesin adalah salah satu elemen yang juga memengaruhi mutu tembakau Besuki Na-Oogst di PTPN X Kebun Kertosari. Penggunaan mesin selama proses pengolahan terbatas pada mesin penggilingan (mesin presing/ pengebalan). Akar elemen mesin pada penelitian ini terdiri dari 2 akar, yaitu:

\section{Kondisi Mesin}

Mesin yang digunakan pada pengusahaan tembakau Besuki Na-Oogst di PTPN X Kebun Kertosari terbatas pada mesin pengemasan, terdapat 2 mesin pressing tenaga listrik dan 1 mesin pressing manual. Mesin yang digunakan hanya mesin listrik sedangkan mesin manual tidak digunakan karena membahayakan keselamatan petugas dan membutuhkan biaya besar. Adanya oli/ cairan pelumas mesin dan benda tajam seperti jarum, paku pada mesin dapat merusak mutu tembakau saat proses pengebalan, kerusakan tersebut berupa sobek dan cacat pada tembakau yang tidak dapat dilihat oleh petugas. 
Keterbatasan sarana dan pasarana

Proses pengolahan tembakau opstapel menjadi tembakau siap ekspor menggunakan sarana dan prasarana sederhana/tradisional dan bersifat umum, belum ada sarana khusus yang mampu meningkatkan mutu tembakau, seperti mesin sortasi, penjahit kemasan dan mesin kontrol kualitas tembakau (aroma, daya bakar, rasa dan lain-lain), semua dilakukan secara manual.

\section{Lingkungan}

Lingkungan adalah faktor eksternal yang berpengaruh terhadap mutu tembakau Besuki Na-Oogst di PTPN $\mathrm{X}$ Kebun Kertosari. Faktor lingkungan ini, yaitu cuaca ekstrim. Cuaca merupakan elemen yang tidak dapat diprediksi, sehingga perlu antisipasi dan perlakuan terhadap perubahan cuaca. Cuaca ekstrim ini berpengaruh pada tahap budi daya, pengeringan dan pengolahan tembakau.

\section{Pengaruh tekanan cuaca ekstrim}

Cuaca ekstrim berpengaruh pada tahapan budi daya, pengasapan dan pengolahan. Pada tahap budi daya, panas menyebabkan tembakau berwarna kekuningan. Dingin menyebabkan tembakau tumbuh tidak normal dan lemas, tembakau ini harus direkondisi terlebih dahulu dan tidak boleh tercampur tembakau sehat. Pada tahap pengasapan panas menyebabkan kemasakan daun tidak sempurna dan daun menjadi keras. Dingin menyebabkan tembakau busuk dan lemas. Pada saat pengolahan, cuaca panas menyebabkan kemasakan fermentasi tidak sempurna dan tembakau menjadi keras, dingin menyebabkan tembakau busuk dan lemas.

Keterbatasan perlakuan cuaca ekstrim

Perlakuan terhadap tekanan cuaca juga sangat berpengaruh terhadap mutu, pada proses budi daya perlakuannya terletak di pengairan, tembakau diberikan air sesuai kebutuhannya. Pada pengasapan perlakuan terletak pada asapan dan jendela gudang, jika tembakau mentah dan lemas maka anglo dan asap diperbanyak dan jendela ditutup, jika tembakau keras maka anglo dikurangi dan jendela gudang dibuka agar sirkulasi udara dapat melemaskan daun tembakau. Pada tahap pengolahan, jika udara panas maka lantai dibasahi dengan air dan jendela gudang dibuka, apabila cuaca dingin, jendela gudang ditutup dan diletakkan anglo pada sekeliling ruangan.

\section{Diagram Pareto Mutu Mutu Tembakau Besuki $\mathrm{Na}$ - Oogst PTPN X Kebun Kertosari}

Tahap kedua analisis mutu tembakau Besuki Na-Oogst PTPN X Kebun Kertosari, yaitu dianalisis dengan diagram pareto untuk menentukan permasalahan utama. Permasalahan ditentukan dari analisis diagram tulang ikan, kemudian dilakukan pembobobtan frekuensi masalah, akumulasi frekuensi, presentase dan akumulasi presentase.

Berdasarkan pada Tabel 1 dapat diketahui bahwa penyebab permasalahan tertinggi, yaitu kelalaian tenaga kerja dengan frekuensi sebanyak 80 kali $(13,2 \%)$ dan penyebab permasalahan terendah, yaitu 7 kali $(1,16 \%)$. Diagram Pareto pada Gambar 3 menunjukkan bahwa penurunan mutu Tembakau Besuki Na-Oogst di PTPN $\mathrm{X}$ Kebun Kertosari disebabkan karena permasalahan utama, yaitu kelalaian dan kurangnya keterampilan petugas. Penyebab tersebut merupakan bagian dari SDM

\section{Strategi Peningkatan Kinerja Mutu Tembakau Besuki Na-Oogst PTPN X Kebun Kertosari}

Strategi alternatif peningkatan kinerja mutu tembakau Besuki Na-Oogst PTPN X Kebun Kertosari dianalisis dengan AHP. Penyusunan hierarki strategi perbaikan kinerja mutu tembakau Besuki Na-Oogst dilakukan dengan menentukan tujuan, sasaran yang ingin dicapai, faktor yang berperan dan strategi alternatif. Tujuan dari proses hierarki analitik pada penelitian ini, yaitu peningkatan mutu tembakau Besuki Na-Oogst PTPN $\mathrm{X}$ Kebun Kertosari. Sasaran yang ingin dicapai yatu dibidang SDM, metode, bahan baku, mesin dan lingkungan. Faktor yang berperan dalam proses hierarki analitik, yaitu keterampilan SDM, proses produksi, kualitas bahan baku, teknik dan teknologi serta cuaca. Penetapan strategi alternatif menggunakan diskusi bersama empat responden ahli, yaitu manajer pengolahan, asisten manajer pengolahan dan dua orang juru teknis yang dianggap ahli dalam bidangnya. Hasil proses penetapan strategi, yaitu kualitas SDM, research and development, sarana proses produksi, sistem proses terintegrasi dan treatment. 
Tabel 1. Analisis permasalahan penurunan mutu tembakau Besuki Na-Oogst PTPN X Kebun Kertosari

\begin{tabular}{lccccc}
\hline \multicolumn{1}{c}{ Permasalahan } & & Frekuensi & $\begin{array}{c}\text { Akumulasi } \\
\text { Frekuensi }\end{array}$ & $\begin{array}{c}\text { Presentase } \\
(\%)\end{array}$ & $\begin{array}{c}\text { Akumulasi } \\
\text { Presentasi (\%) }\end{array}$ \\
\hline Kelalaian tenaga kerja & 1 & 80 & 80 & 13,2 & 13,22 \\
Kurangnya keterampilan TK & 2 & 78 & 158 & 12,9 & 26,12 \\
Pengaruh tekanan cuaca ekstrim & 3 & 69 & 227 & 11,4 & 37,52 \\
Keterbatasan perlakuan cuaca ekstrim & 4 & 67 & 294 & 11,1 & 48,60 \\
Keterbatasan pengalaman tenaga kerja & 5 & 65 & 359 & 10,7 & 59,34 \\
Usia tenaga kerja & 6 & 60 & 419 & 9,92 & 69,26 \\
Keterbatasan perlakuan produksi & 7 & 48 & 467 & 7,93 & 77,19 \\
Kurangnya research and development & 8 & 35 & 502 & 5,79 & 82,98 \\
Kesalahan sortasi tembakau & 9 & 30 & 532 & 4,96 & 87,93 \\
Keterbatasan sarana produksi & 10 & 23 & 555 & 3,80 & 91,74 \\
Kesalahan masak fermentasi & 11 & 16 & 571 & 2,64 & 94,38 \\
Kesalahan masak petik & 12 & 9 & 580 & 1,49 & 95,87 \\
Kesalahan masak curing & 13 & 9 & 589 & 1,49 & 97,36 \\
Kesalahan saring rompos & 14 & 9 & 598 & 1,49 & 98,84 \\
Kondisi mesin & 15 & 7 & 605 & 1,16 & 100 \\
\hline \multicolumn{1}{c}{ Total } & 605 & & 100 & \\
\hline
\end{tabular}

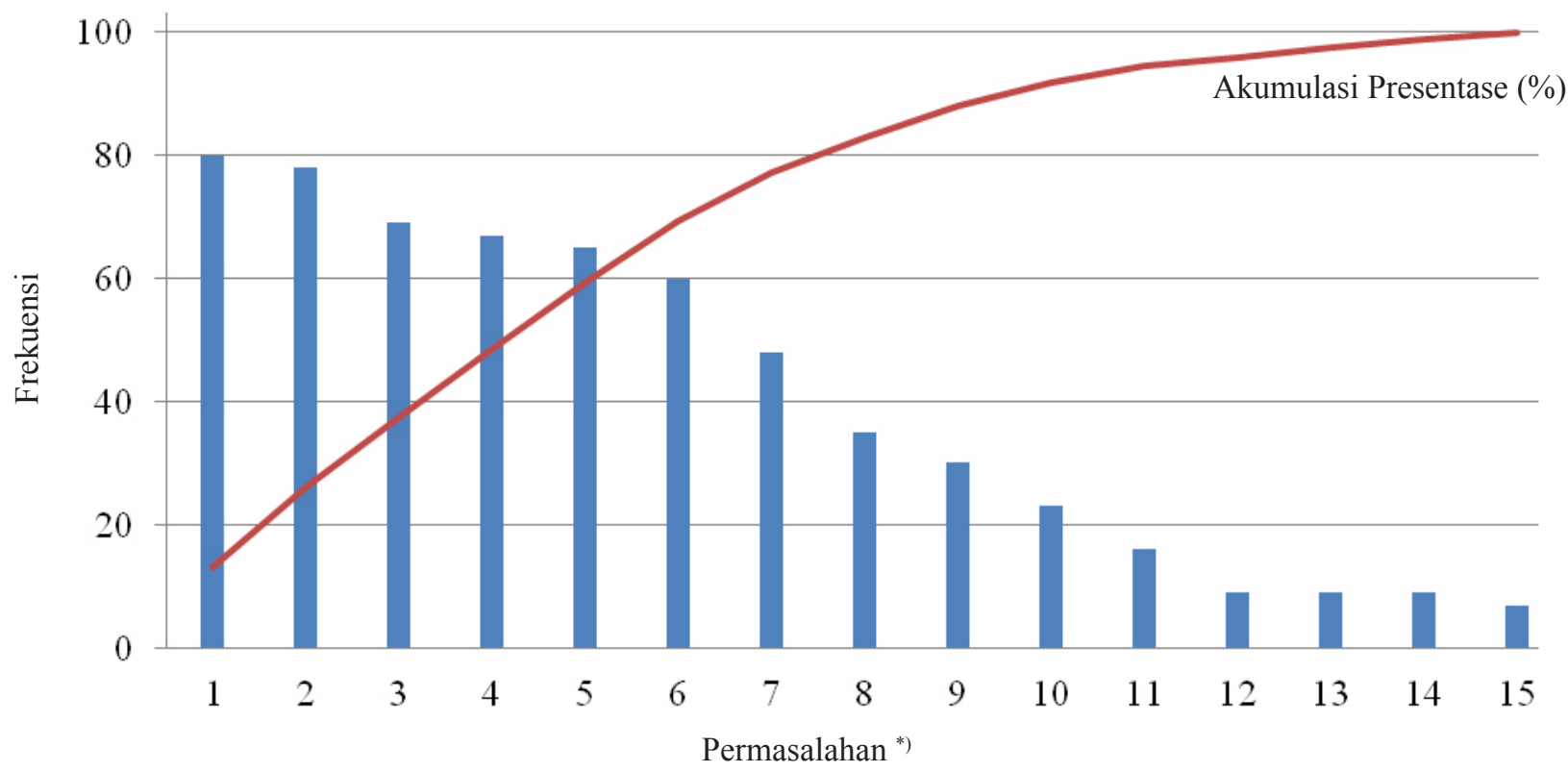

Keterangan: *) dilihat pada permasalahn di Tabel 1

Gambar 3. Diagram pareto penurunan mutu tembakau Besuki Na-Oogst di PTPN X Kebun Kertosari

\section{Pairwise Comparison Hierarki Peningkatan Mutu Tembakau Besuki Na-Oogst PTPN X Kertosari}

Penentuan strategi alternatif perbaikan kinerja mutu Tembakau Besuki Na-Oogst PTPN X Kebun Kertosari dilakukan dengan perbandingan berpasangan (pairwise comparison) dengan perangkat lunak expert choice 11. Terdapat beberapa tingkat perbandingan, yaitu tingkat 1 perbandingan sasaran untuk menentukan prioritas dari tujuan, tingkat dua perbandingan faktor yang berperan untuk mengetahui sasaran yang harus diprioritaskan dan perbandingan ditingkat tiga, yaitu perbandingan strategi untuk mengetahui strategi alternatif yang diprioritaskan. Bagan AHP peningkatan kinerja mutu tembakau Besuki Na-Oogst PTPN X Kebun Kertosari pada Gambar 4. 


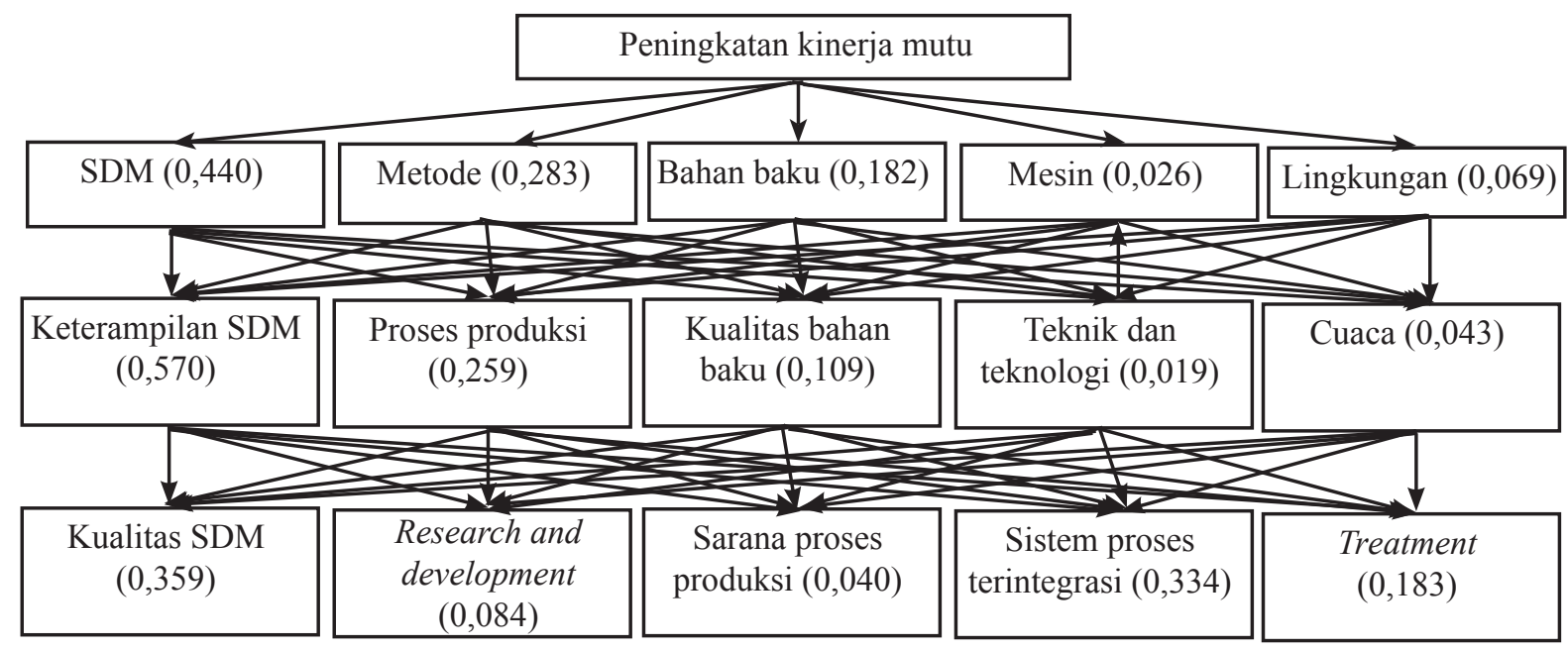

Gambar 4. Struktur hierarki kinerja mutu tembakau Besuki Na-Oogst PTPN X Kebun Kertosari

Berdasarkan Gambar 4 didapatkan informasi bahwa struktur hierarki peningkatan mutu tembakau Besuki Na-Oogst di PTPN X Kebun Kertosari menggunakan software expert choice 11 diperoleh bobot tertinggi SDM $(0,440)$. Hasil analisis metode $(0,283)$, bahan baku $(0,182)$, mesin $(0,026)$, dan lingkungan $(0,069)$. Oleh karena itu, SDM merupakan hierarki yang perlu diutamakan atau diprioritaskan. Adapun faktor yang mendukung SDM, yaitu keterampilan SDM yang memiliki bobot sebesar $(0,570)$.

Hasil penelitian ini sesuai dengan penelitian Zusrony (2013) yang berjudul "Pengaruh Penerapan Peran Total Quality Management (TQM) Terhadap Kualitas Sumberdaya Manusia", penelitian oleh Sularso dan Murdijanto (2004) dan peneliian yang dilakukan oleh Batubara (2016) serta penelitian oleh Semuel (2003) menyatakan bahwa SDM merupakan komponen yang berperan penting terhadap keberhasilan penerapan TQM. Artinya, penelitian ini sejalan dengan penelitian sebelumnya yang pernah dilakukan dalam ruang lingkup TQM.

Hasil komputasi strategi alternatif untuk meningkatkan kinerja mutu tembakau Besuki Na-Oogst di PTPN $\mathrm{X}$ Kebun Kertosari diperoleh strategi kualitas SDM $(0,359)$, research and development $(0,084)$, sarana proses produksi $(0,040)$, sistem proses terintegrasi $(0,334)$, dan treatment $(0,183)$. Hasil tersebut menunjukkan bahwa bobot strategi tertinggi, yaitu kualitas SDM, dapat diinterpretasikan bahwa kualitas SDM merupakan strategi utama atau strategi yang diprioritaskan, sedangkan strategi pendukung berturut- turut, yaitu sistem proses terintegrasi, treatment, research and development. Strategi terakhir, yaitu sarana proses produksi.

Sumber Daya Manusia (SDM) adalah penanggung jawab dan penggerak suatu kegiatan. Kualitas suatu produk dapat di kendalikan oleh SDM. SDM yang terampil mampu menghasilkan tembakau yang baik dengan keterampilan dan kemampuan yang dimiliki melalui bantuan sarana prasarana, teknologi dan perlakuan yang dikombinasikan dengan baik. Begitu pula sebaliknya, SDM yang tidak berkualitas dapat memberikan penanganan yang salah dapat menyebabkan gagal produk. Semua kegiatan ini berada dibawah kendali SDM. Faktor yang paling berpengaruh terhadap peningkatan kinerja mutu tembakau Besuki Na-Oogst di PTPN X Kebun kertosari adalah SDM dengan strategi peningkatan kualitas SDM sebagai strategi utama dan strategi pendukung, yaitu adanya sistem proses terintegrasi, perbaikan treatment, pengembangan research and development serta tersedianya sarana proses produksi yang lengkap.

\section{Implikasi Manajerial}

Implikasi manajerial yang diperoleh dari penelitian ini adalah PTPN X Kebun Kertosari, yaitu perlu adanya pendampingan dan monitoring yang lebih intensif terhadap seluruh kegiatan produksi tembakau untuk mengurangi adanya kelalaian dan kesalahan tenaga kerja pada saat berproduksi, terutama di bagian fermentasi dan sortasi, karena tahapan tersebut yang sangat menentukan mutu tembakau. 


\section{KESIMPULAN DAN SARAN}

\section{Kesimpulan}

Hasil penelitian menunjukkan bahwa mutu tembakau Besuki Na-Oogst di PTPN X Kebun Kertosari tidak mampu mencapai target disebabkan oleh beberapa elemen, yaitu SDM, metode, bahan baku, mesin dan lingkungan. Penyebab utama terjadinya penurunan mutu tembakau Besuki Na-Oogst di PTPN X Kebun Kertosari, yaitu kelalaian tenaga kerja dan kurangnya keterampilan tenaga kerja.

Analisis AHP menunjukkan bahwa strategi alternatif yang dapat dilakukan untuk peningkatan kinerja mutu tembakau Besuki Na-Oogst di PTPN X Kebun Kertosari, yaitu peningkatan kualitas SDM sebagai startegi utama dan yang lainnya merupakan strategi pendukung, yaitu research and development, sarana proses produksi, sistem proses terintegrasi, dan treatment.

\section{Saran}

Perlu adanya pelatihan khusus agar tercipta tenaga kerja yang terampil dan peka terhadap kondisi tembakau. Perlu adanya sosialisasi dan aplikasi secara reguler mengenai teknologi baru dan perubahan metode produksi baru yang berpengaruh terhadap peningkatan mutu tembakau Besuki Na-Oogst di PTPN X Kebun Kertosari. Saran untuk penelitian selanjutnya, yaitu perlu adanya penelitian lebih lanjut dan mendalam terkait peningkatan mutu tembakau Besuki Na-Oogst di PTPN X Kebun Kertosari mulai dari tahap budi daya, pengeringan sampai pengolahan.

\section{DAFTAR PUSTAKA}

Batubara S. 2016. Pengaruh penerapan peran total quality management terhadap kualitas sumber daya manusia pada PT Surya Pratama di Medan. Jurnal Ilmiah Research Sains 2(1): 23-32.

Chandra JC. 2013. Implementasi pengendalian kualitas dengan menggunakan metode statistik pada PT Diantrijaya Utama Muktidi Surabaya. Calyptra 2(2): 1-17.

Darmasetiawan N, Istiko AW. 2012. Pengaruh faktor internal petani terhadap peningkatan mutu tembakau di Desa Pacekelan Kec. Purworejo
Kabupaten Purworejo. Surya Agritama 1(1): 48-58.

Diatin I, Fannayanti N, Lesmana ZE. 2006. Analisis biaya kegagalan internal pengendalian mutu proouk udang beku (Frozen Shrimp) pada PT Def, Muara Baru, Jakarta. Buletin Ekonomi Perikanan 6(2): 30-41.

Djarwadi. 2012. Analisis hierarki proses untuk pengembangan minyak atsiri. Jurnal Sains dan Teknologi Indonesia 14(1): 17-23.

Hastuti DDP. 2010. Proses Hierarki Analisis (AHP) dalam pengambilan keputusan multikriteria [Skripsi] Yogyakarta: Universitas Negeri Yogyakarta.

Ishikawa K. 1989. Teknik Penuntun Pengendalian Mutu. Jakarta: PT Mediyatama Sarana Perkasa.

Mayangsari D, Hadi SP, Hidayat W. 2014. Pengaruh peran total quality management dan kompensasi terhadap kualitas sumber daya manusia PT. Djarum (studi kasus pada pabrik BL 53 Kudus). Diponegoro Journal of Social and Politic 2014: 1-8.

Nasution MN. 2005. Manajemen Mutu Terpadu. Bogor: Ghalia Indonesia.

Putri EA, Suwandari A, Ridjal JA. 2015. Analisis pendapatan dan efisiensi biaya usahatani tembakau maesan 2 di Kabupaten Bondowoso. Jurnal Sosial Ekonomi Pertanian 8(1): 64-69.

Ramadhani GS, Wilandari Y, Suparti S. 2014. Analisis pengendalian kualitas menggunakan diagram kendali demerit (studi kasus produksi air minum dalam kemasan 240 Ml di PT TIW). Jurnal Gaussian 3(3): 401-410.

Rusdianto AS, Novijanto N, Alihsany R. 2011. Penerapan statistical quality control (SQC) pada pengolahan kopi robustacara semi basah. Jurnal Agrotek 5(2): 1-16.

Semuel H. 2003. Penerapan total quality management suatu evaluasi melalui karakteristik kerja. Jurnal Manajemen \& Kewirausahaan 5(1): 72-84.

Soetjitro P. 2010. Instrumen total quality management (TQM) sebagai pilihan alat pengendalian. Value Added 6 (2): 49-60.

Sularso RA, Murdijanto. 2004. Pengaruh penerapan peran total quality management terhadap kualitas sumberdaya manusia. Jurnal Manajemen \& Kewirausahaan 6(1): 72-81.

Tisnowati H, Hubeis M, Hardjomidjojo H. 2008. Analisis pengendalian mutu produksi roti (Kasus PT. AC, Tangerang). Manajemen IKM: Jurnal Manajemen Pengembangan Industri Kecil 
Menengah 3(1): 51-61.

Utami SW, Daryanto A, Rujito H. 2014. Strategi peningkatan dayasaing tembakau besuki naoogst berbasis perbaikan kinerja mutu. Jurnal Manajemen dan Agribisnis 11(2): 100-109.

Widyastutik, Arianti RK. 2013. Strategi kebijakan mutu dan standar produk ekspor dalam meningkatkan dayasaing (Studi kasus produk ekspor biji kakao. Jurnal Manajemen \& Agribisnis 10(2): 98-108.

Zusrony E. 2013. Pengaruh Penerapan Peran Total Quality Management terhadap kualitas sumberdaya manusia (Studi Kasus pada PT. BFI Finance Tbk.). BENEFIT Jurnal Manajemen dan Bisnis 17(1): 51-57. 